\title{
Front Matter: Volume 9346
}

, "Front Matter: Volume 9346," Proc. SPIE 9346, Components and Packaging for Laser Systems, 934601 (16 April 2015); doi: 10.1117/12.2183976

SPIE. Event: SPIE LASE, 2015, San Francisco, California, United States 


\title{
PROCEEDINGS OF SPIE
}

\section{Components and Packaging for Laser Systems}

\author{
Alexei L. Glebov \\ Paul O. Leisher \\ Editors
}

9-12 February 2015

San Francisco, California, United States

Sponsored and Published by

SPIE 
The papers included in this volume were part of the technical conference cited on the cover and title page. Papers were selected and subject to review by the editors and conference program committee. Some conference presentations may not be available for publication. The papers published in these proceedings reflect the work and thoughts of the authors and are published herein as submitted. The publisher is not responsible for the validity of the information or for any outcomes resulting from reliance thereon.

Please use the following format to cite material from this book:

Author(s), "Title of Paper," in Components and Packaging for Laser Systems, edited by Alexei L. Glebov, Paul O. Leisher, Proceedings of SPIE Vol. 9346 (SPIE, Bellingham, WA, 2015) Article CID Number.

ISSN: 0277-786X

ISBN: 9781628414363

Published by

SPIE

P.O. Box 10, Bellingham, Washington 98227-0010 USA

Telephone +1 3606763290 (Pacific Time) · Fax +1 3606471445

SPIE.org

Copyright (C) 2015, Society of Photo-Optical Instrumentation Engineers.

Copying of material in this book for internal or personal use, or for the internal or personal use of specific clients, beyond the fair use provisions granted by the U.S. Copyright Law is authorized by SPIE subject to payment of copying fees. The Transactional Reporting Service base fee for this volume is $\$ 18.00$ per article (or portion thereof), which should be paid directly to the Copyright Clearance Center (CCC), 222 Rosewood Drive, Danvers, MA 01923. Payment may also be made electronically through CCC Online at copyright.com. Other copying for republication, resale, advertising or promotion, or any form of systematic or multiple reproduction of any material in this book is prohibited except with permission in writing from the publisher. The CCC fee code is 0277-786X/15/\$18.00.

Printed in the United States of America.

Publication of record for individual papers is online in the SPIE Digital Library.

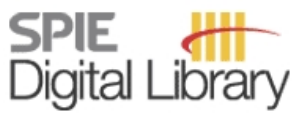

SPIEDigitalLibrary.org

Paper Numbering: Proceedings of SPIE follow an e-First publication model, with papers published first online and then in print. Papers are published as they are submitted and meet publication criteria. A unique citation identifier (CID) number is assigned to each article at the time of the first publication. Utilization of CIDs allows articles to be fully citable as soon as they are published online, and connects the same identifier to all online, print, and electronic versions of the publication. SPIE uses a six-digit CID article numbering system in which:

- The first four digits correspond to the SPIE volume number.

- The last two digits indicate publication order within the volume using a Base 36 numbering

system employing both numerals and letters. These two-number sets start with 00, 01, 02, 03, 04, $05,06,07,08,09,0 A, 0 B \ldots$. OZ, followed by 10-1Z, 20-2Z, etc.

The CID Number appears on each page of the manuscript. The complete citation is used on the first page, and an abbreviated version on subsequent pages. 


\title{
Contents
}

\author{
vii Authors \\ ix Conference Committee \\ xi Introduction
}

SESSION 1 LASER DIODE PACKAGING AND COMPONENTS: JOINT SESSION WITH CONFERENCES 9346 AND 9348

934602 Beam vignetting effect in micro-optic collimation and transmission for high power diode laser arrays [9346-1]

934603 High-brightness power delivery for fiber laser pumping: simulation and measurement of low-NA fiber guiding [9346-2]

934604 High power diode laser stack development using gold-tin bonding technology [9346-3]

\section{SESSION 2 LD COMPONENTS AND PACKAGING I}

934605 Advances in bonding technology for high power diode laser bars (Invited Paper) [9346-4]

934606 Innovative hybrid heat sink materials with high thermal conductivities and tailored CTE [9346-5]

934607 Effect of interface layer on the performance of high power diode laser arrays [9346-6]

934608 760nm: a new laser diode wavelength for hair removal modules [9346-7]

\section{SESSION 3 LD COMPONENTS AND PACKAGING II}

9346 OC Effects of packaging on the performances of high brightness 9xx nm CW mini-bar diode lasers [9346-11]

\section{SESSION 4 OPTICS ASSEMBLY AND RELIABILITY I}

$9346 \mathrm{OE}$ Strategies for precision adhesive bonding of micro-optical systems [9346-13]

9346 OF Airborne molecular contamination: quality criterion for laser and optical components [9346-14] 
$9346 \mathrm{OH}$ Space qualification of the optical filter assemblies for the ICESat-2/ATLAS instrument [9346-16]

$9346 \mathrm{Ol} \quad$ Virtual commissioning of automated micro-optical assembly [9346-17]

$93460 \mathrm{~J} \quad$ Review of polarization techniques for optimal performance of one and two color wavelength laser range finders and designators [9346-18]

9346 OK Adjustable mounting device for high-volume production of beam-shaping systems for high-power diode lasers [9346-19]

\section{SESSION 6 SOLID-STATE AND FIBER LASER COMPONENTS}

9346 OM Lithium niobate Q-switch to prevent pre-lasing of high gain lasers operating over a wide temperature range [9346-21]

9346 ON Rigorous modeling of laser light propagation through uniaxial and biaxial crystals [9346-22]

934600 Optical isolators for 2-micron fibre lasers [9346-23]

\section{SESSION 7 BEAM MANIPULATION AND DELIVERY}

$93460 Q \quad$ Achromatic phase elements based on a combination of surface and volume diffractive gratings [9346-25]

9346 OR Refractive beam shapers for optical systems of lasers [9346-26]

\section{SESSION 8 HIGH POWER/ENERGY LASER COMPONENTS}

9346 OT Diamond optical components for high-power and high-energy laser applications [9346-28]

9346 OU BBO sapphire compound for high-power frequency conversion [9346-29]

9346 OV Solid-state laser source of narrowband ultraviolet B light for skin disease care with advanced performance [9346-30]

9346 OW Demonstration of $>5 \mathrm{~kW}$ emissions with good beam quality from two different 7:1 all-glass fiber coupler-types [9346-31]

9346 OX Photothermal studies of the radiation effects on weakly absorptive optical thin film coatings induced by high repetitive laser pulses [9346-32] 
$93460 Z$ Kagome-type hollow-core photonic crystal fibers for beam delivery and pulse compression of high-power ultrafast lasers (Invited Paper) [9346-34]

934611 Adaptive optics for ultra short pulsed lasers in UHV environment [9346-36]

\section{SESSION 10 BEAM COMBINING TECHNIQUES}

934614 Beam combining techniques for high-power high-brightness diode lasers [9346-40]

POSTER SESSION

$934615 \quad$ Building beam shaping optics for micromachining [9346-41]

934616 Modeling laser beam propagation through components with internal multiple reflections [9346-42]

934619 Integrated RGB laser light module for autostereoscopic outdoor displays [9346-45]

9346 lA Characterization of far field of diode laser by three dimensional measurement [9346-46] 
Proc. of SPIE Vol. $9346934601-6$

Downloaded From: https://www.spiedigitallibrary.org/conference-proceedings-of-spie on 26 Apr 2023 Terms of Use: https://www.spiedigitallibrary.org/terms-of-use 


\title{
Authors
}

Numbers in the index correspond to the last two digits of the six-digit citation identifier (CID) article numbering system used in Proceedings of SPIE. The first four digits reflect the volume number. Base 36 numbering is employed for the last two digits and indicates the order of articles within the volume. Numbers start with 00, 01, 02, 03, 04, 05, 06, 07, 08, 09, OA, OB...0Z, followed by 10-1Z, 20-2Z, etc.

\author{
Anoikin, Eugene, OT \\ Asoubar, Daniel, ON \\ Avila, Marco A., OJ \\ Bartelt, H., OW \\ Baskin, llya, 03 \\ Benabid, F., OZ \\ Bennett, Andrew, OT \\ Berk, Yuri, 03 \\ Bernhardt, Henning, OK \\ Bradshaw, H. N., OH \\ Brecher, Christian, OE, OI, OK \\ Buchwald, Kristian, OV \\ Cai, Lei, 04 \\ Chen, Jian, OX \\ Chu, Hong, OV \\ Cook, W. B., $\mathrm{OH}$ \\ Cui, Long, IA \\ Czernecki, Robert, 19 \\ Dahan, Nir, 03 \\ Dai, Ye, 04 \\ de Vries, O., OW \\ de Wit, Henk, OT \\ Debord, B., OZ \\ Deneuville, Francois, 11 \\ Denny, Z. H., $\mathrm{OH}$ \\ Diebold, A., OZ \\ Divliansky, Ivan, $O Q$ \\ Dong, Jingtao, $\mathrm{OX}$ \\ Eberhardt, Ramona, OU, OW \\ Emaury, F., OZ \\ Eschrich, T., OW \\ Feng, Feifei, 05, 0C \\ Fidler, Franz, 19 \\ Forrer, H., 02 \\ Forrer, M., 02 \\ Fritsche, Haro, 14 \\ Gérôme, F., $\mathrm{OZ}$ \\ Glebov, Leonid B., $0 Q$ \\ Gries, Wolfgang, 14 \\ Grohe, Andreas, 14 \\ Haag, Sebastian, OE, OI, OK \\ Hagen, Thomas, 14 \\ Hale, Evan, $0 Q$ \\ Hambeck, Christian, 19 \\ Haverkamp, Tobias, OK \\ Hou, Dong, 04, 05, 07 \\ Huber, M., 02 \\ Hülsewede, Ralf, 08 \\ Hults, J. A., $\mathrm{OH}$
}

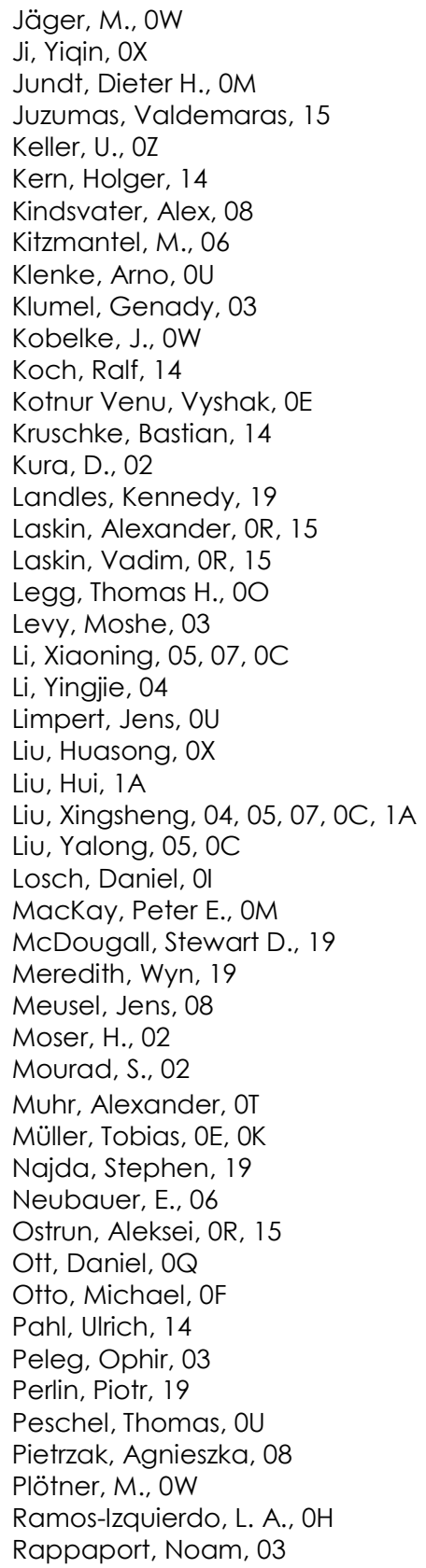


Reitterer, Jörg, 19

Ropert, Laurent, 11

Roßmann, Jürgen, ol

Rothhardt, Carolin, OU

Rothhardt, Jan, OU

Rübenach, Olaf, OK

Saint Julien-Wallsee, Ferdinand, 19

Saleh, Bahaa E. A., OQ

Saraceno, C. J., $\mathrm{OZ}$

Saver, Sebastian, OE

Sauvageot, Paul, 11

Schlette, Christian, 01

Schmid, Ulrich, 19

Schmidlin, M., 02

Schreiber, T., OW

Schriber, C., OZ

Sebastian, Jürgen, 08

SeGall, Marc, $0 Q$

Shamay, Moshe, 03

Shardlow, Peter, 00

Šlekys, Gintas, 15

Smith, K. A., $\mathrm{OH}$

Stanczyk, Szymon, 19

Stevens, Gary, 00

Südmeyer, T., $0 Z$

Tarasov, Aleksandr A., OV

Theis, Sébastien, 11

Troupaki, E., $\mathrm{OH}$

Tünnermann, Andreas, OU, OW

Twitchen, Daniel, OT

Unger, S., OW

Urniežius, Aivaras, 15

Vickers, Garrie, 19

Wang, Jingwei, 04, 05, 07, 0C

Wang, Zongzhao, 16

Wenzel, Christian, OE

Wölz, Martin, 08

Wu, Di, 1A

Wu, S., $\mathrm{OH}$

Wu, Zhouling, OX

Wyrowski, Frank, 0N, 16

Xiong, Lingling, 07

Yanson, Dan, 03

Yu, Dongshan, OC

Yuan, Zhiyuan, $1 \mathrm{~A}$

Zeldovich, Boris Y., OQ

Zhang, Pu, 04, 07, OC

Zhang, Site, $0 \mathrm{~N}, 16$

Zontar, Daniel, OE, OI, OK

Zorn, Martin, 08 


\section{Conference Committee}

Symposium Chairs

Guido Hennig, Daetwyler Graphics AG (Swtizerland)

Yongfeng Lu, University of Nebraska-Lincoln (United States)

Symposium Co-chairs

Bo Gu, Bos Photonics (United States)

Andreas Tünnermann, Fraunhofer-Institut für Angewandte Optik und Feinmechanik (Germany) and Friedrich-Schiller-Universität Jena (Germany)

Program Track Chair

Gregory J. Quarles, Optoelectronics Management Network (United States)

Conference Chairs

Alexei L. Glebov, OptiGrate Corporation (United States)

Paul O. Leisher, Rose-Hulman Institute of Technology (United States)

Conference Program Committee

Igor Anisimov, Air Force Research Laboratory (United States)

Kristian J. Buchwald, Ibsen Photonics A/S (Denmark)

Te-Yuan Chung, National Central University (Taiwan)

Joseph L. Dallas, Avo Photonics, Inc. (United States)

Martin Forrer, FISBA OPTIK AG (Switzerland)

Daniel M. Grasso, Coherent, Inc. (United States)

Michael A. Karavitis, Cutera, Inc. (United States)

Alexander V. Laskin, AdlOptica Optical Systems GmbH (Germany)

Victor Liu, Xi'an Focuslight Technologies Co., Ltd. (China)

Jens Meinschien, LIMO Lissotschenko Mikrooptik GmbH (Germany)

Christian V. Poulsen, NKT Photonics Inc. (United States)

Mark A. Stephen, NASA Goddard Space Flight Center (United States)

Takunori Taira, Institute for Molecular Science (Japan)

Torsten Vahrenkamp, ficonTEC Service GmbH (Germany)

Alexander Yusim, IPG Photonics Corporation (United States)

Arnaud Zoubir, ALPhANOV (France) 
Session Chairs

1 Laser Diode Packaging and Components: Joint Session with Conferences 9346 and 9348

Paul O. Leisher, Rose-Hulman Institute of Technology (United States)

Kurt J. Linden, N2 Biomedical (United States)

2 LD Components and Packaging I

Joseph Lovis Dallas, Avo Photonics, Inc. (United States)

3 LD Components and Packaging II

Jingwei Wang, Xi'an Focuslight Technologies Co., Ltd. (China)

4 Optics Assembly and Reliability I

Torsten Vahrenkamp, ficonTEC Service GmbH (Germany)

5 Optics Assembly and Reliability II

Martin Forrer, FISBA OPTIK AG (Switzerland)

6 Solid-State and Fiber Laser Components

Alexander Yusim, IPG Photonics Corporation (United States)

7 Beam Manipulation and Delivery

Te-Yuan Chung, National Central University (Taiwan)

8 High Power/Energy Laser Components

Thomas Mitra, LIMO Lissotschenko Mikrooptik GmbH (Germany)

9 Components for Ultra-Short Pulse Lasers

Christian V. Poulsen, NKT Photonics Inc. (United States)

10 Beam Combining Techniques

Alexei L. Glebov, OptiGrate Corporation (United States) 


\section{Introduction}

Optical components are crucial for laser performance and form a foundation for advances in laser science and technology. All around the globe, vast and constantly growing research efforts are dedicated to developing new and more advanced laser components and systems. Along this line, packaging solutions for optical components enable their most efficient and consistent integration in laser systems. Laser component packaging is decisive for stable and reliable laser operations while not only improving laser characteristics but also enabling broader laser usability and applications.

Cross-listed between the LASE and OPTO symposia of SPIE Photonics West, the Components and Packaging for Laser Systems conference is primarily focused on achievements and progress made in the field of optical components and packaging technology for laser systems such as semiconductor lasers, solid state lasers, fiber lasers, gas lasers, continuous-wave and pulsed lasers, ultra-short pulsed lasers, and others. Examples of optical components for lasers include macro- and micro-optic lenses and arrays, diffractive and holographic elements, coating technology, polarization optics, fiber optic connectors, couplers, splitters, and isolators, laser gain media, beam transformation systems, components for ultra-short pulsed lasers, components for coherent and spectral beam combining, mid-IR elements, novel design methodologies, and advanced manufacturing techniques. Examples of packaging technology include assembly and mounting solutions of optical components, thermal management and packaging approaches in high-power lasers, laser array packaging and lensing, novel active and passive alignment techniques, laser system reliability, and package modelling.

This conference was created to address a gap in the technical program at Photonics West. Specifically, the developers working on component and packaging technologies (especially those common to several classes of laser systems) did not have a dedicated venue where they could present to their colleagues, customers, and suppliers. Prior to the creation of this conference, such talks would either be relegated to conferences specific to one laser system class, or more commonly, not be presented at all. In this inaugural year, our strong international committee comprising engineers and scientists from academia and industry did an outstanding job of building up and promoting this new conference, as evidenced by the large number of high quality papers we received. We were also delighted to see very strong attendance of the presentations throughout the week, and before an overflow room was designated, almost all seats were filled with many standees backed up into the hallway. 
In closing, we are very thankful to the committee, authors, and attendees who made this year such a great success and we are looking forward to an even better conference next year.

\section{Alexei L. Glebov \\ Paul O. Leisher}

